Review Article

\title{
The Passing Fads and Emergent Trends of Project Culture in Construction Industry
}

\author{
Qinghua He, ${ }^{1}$ Jin Li, ${ }^{1}$ Jingyuan Wan, ${ }^{1}$ Zhenyu Zhang $\mathbb{D}^{1,2,3}$ and Zhen Chen ${ }^{4}$ \\ ${ }^{1}$ School of Economics and Management, Tongji University, Shanghai 20092, China \\ ${ }^{2}$ School of Automation, Nanjing University of Science \& Technology, Nanjing, China \\ ${ }^{3}$ Shanghai Municipal Engineering Design Institute (Group) Co., Ltd., Shanghai 200092, China \\ ${ }^{4}$ School of Economics and Management Engineering, Beijing University of Civil Engineering and Architecture, \\ Beijing 100044, China
}

Correspondence should be addressed to Zhenyu Zhang; zhangzhenyu7@foxmail.com

Received 18 October 2019; Revised 22 June 2020; Accepted 24 July 2020; Published 24 August 2020

Academic Editor: Abdul Aziz Bin Abdul Samad

Copyright (C) 2020 Qinghua He et al. This is an open access article distributed under the Creative Commons Attribution License, which permits unrestricted use, distribution, and reproduction in any medium, provided the original work is properly cited.

Project culture in construction industry is unique, distinguishing one project from others, and plays a role in the processing of construction projects. The aim of this paper is to conduct a holistic review of the extant literature and identify the future trends of project culture. The method of a systematic literature review was conducted to overview the extant articles on project culture in construction industry until 2019. After searching in ISI Web of Science, Scopus, and Google Scholar, we obtained a total number of 31 papers and refinement was made by content analysis. Four aspects were analyzed: the nature of project culture, the diagnosis of project culture, factors influencing project culture, and research focus. It provides a map of project culture from philosophy paradigms. And findings show that research on project culture was mainly from the function paradigm (the integration position) in which culture can be manipulated for better project performance. A few from nonfunction paradigm (the fragment position) stressed sense making of project culture. This study proposes a framework consisting of a hybrid function/nonfunction paradigms and diagnoses project culture from explicit and implicit aspects. These findings make a firm foundation for the exploration of project culture from multiperspectives in theory and practice.

\section{Introduction}

Much attention has been paid to project culture which is significant for completing construction projects. Project culture as the soft science makes for the shortages of technology and becomes a powerful tool for project management. As for construction projects, temporary organisations from different backgrounds work together for special project objectives $[1,2]$. Cross-culture cooperation of those organisations faces acute challenges. Participants have various backgrounds, professions, and even nations, which contribute to the cultural diversity in projects. Collaboration and cooperation may be hindered by these factors during the project. Moreover, the limited resources result in culture of compete or conflict among participants. Project Management Institute [3] highlights that the construction of projects is inseparable from culture, sometimes even multiple cultures. Culture has a significant impact on management in the course of construction project, such as stakeholder management, risk management, and knowledge management [4-7]. Culture has been identified as a key factor for crossorganisation cooperation and even project success. Much attention has been paid to culture issues in construction recently.

Project culture is increasingly popular with practitioners and academics in construction projects $[8,9]$. In the last couple of years, culture issues in construction have gained attention from leading journals on project management [10]. The studies of project culture are mainly divided into two conceptualizations of function paradigms and nonfunction paradigms from the expected outcomes. The function paradigm highlights the control, prediction, and causality 
between culture and performance. For instance, Zuo made a comparison of project culture in construction industry between Australia and China and proposed that innovation performance could be strengthened by project culture [11]. In order to improve project performance, project culture could be manipulated for better project outcomes [11, 12]. The nonfunction paradigm emphasizes the meaning of culture issues and interprets the culture context [13]. For example, Samaraweera et al. shed light on cultural learning in the form of underlying assumptions during conflict or project change [12].

Although reviews on project culture have been done, some questions are still ignored. Firstly, the prior reviews aim at general culture instead of project culture in construction, such as organisation culture and national culture [8]. Secondly, project culture in their reviews is treated as a variable from the function paradigm and can be controlled for better project performance [13]. Most of them simplified project culture to some indicators or superficial form. Finally, reviews on project culture are too old and need to be updated with the newest research $[10,13]$. Tsai and Lydia Wen [14] suggested that a holistic review would assist the researcher to understand the current status and future trends of the chosen topics and could help researchers not to repeat what has already been done. A systematic literature review (SLR) methodology can be a useful tool to explore a specific research area.

Therefore, this paper explores the passing fads and emergent trends of project culture in construction projects with the help of a systematic literature review. In this paper, the sections are set as follows: in Section 2, we elaborate the research of culture in construction projects; in Section 3, we provide the methodology, data collection, and the processing. Then, we present the research results in Section 4, which includes an analysis of the nature of project culture, factors influencing project culture, the extraction of project culture, and research focus. The last section concludes this study and proposes some future directions.

\section{Culture in Construction Projects}

So far, scholars have studied the culture in construction projects from multiple perspectives, such as organisation culture, project management culture, and cross-culture management. These perspectives have sought to uncover the key profiles of project culture. To unveil the nature of project culture, well-established organisational culture models are used for research on project culture. For example, Thomas adopted Cameron and Quinn's Competing Values Framework model to assess project culture. It is simple and convenient to apply the organisational culture models into project culture research. But these studies ignore the uniqueness of projects. From the perspective of project management, project culture is one of the goals of project like time, cost, and quality. Or it refers especially to the culture within the project management department. Notable study of culture in projects is presented by Müller et al. [15], Ankrah and Langford [16], and Rameezdeen and Gunarathna [17]. In addition, from the perspective of cross-culture management, the research mainly studies culture from subcultures, such as professional culture.

Scholars have shed light on culture in construction context recently. Yet, the general definition of culture has always been a matter of dispute and still nascent so far $[18,19]$. On the one hand, there are lots of studies which highlight shared cultural values and project culture in these studies is an attribute of the organisation. On the basis of a well-recognized definition of Schein's organisational culture, for example, Zuo and Zillante [20] defined that project culture is the shared values, basic assumptions, and beliefs of a given project organisation. Furthermore, Hofstede and Hofstede [21] pointed out that culture was the collective programming of the mind, which could differentiate organisations [22]. Project Management Institution [3] deemed that project culture was all the product of human work and thought. These are from the shared perspective called the function paradigm, in which project culture in construction context is defined as "shared" values and assumptions [23-25]. On the other hand, organisation is perceived as project culture from the nonfunction paradigm and project culture aims at sense making and processes of meaning. This can be seen in Alfons Van Marrewijk's study. There are multi differentiate or fragment subcultures in project culture.

In order to accurately decipher culture in construction context, several reviews of culture have been done. Udawatta et al. [26] reviewed how procurement systems impacted project culture and defined project culture from the participants shared perspective, such as the shared values, basic assumptions, and beliefs. Henrie and Sousa-Poza [10] searched 2 journals including International Journal of Project Management and Project Management Journal and 93 books relating to culture in project management from 1993 to 2003. Samaraweera and Senaratne [27] reviewed project culture through subcultures and organisation cultural models and identified project features in construction context. Furthermore, they conducted a literature review on conceptual framework for understanding construction project culture but the reviewed papers published before 2014 [28]. Ankrah and Proverbs [29] found that culture was shaped by practices and in-deep values. Culture in construction was endowed with industry characteristics and affected by the style of management, objectives, strategies, the capability of participants, and ways of construction. Lots of work have been performed, but project culture is still a black box for scholars and managers.

\section{Research Method}

In order to collect the information for this paper, we adopted a systematic literature review (SLR) methodology to analyze the articles published before 2019 on project culture in construction context. The aim of this paper was to investigate and discuss research trends and gaps of project culture research in construction context. Given the purpose of this paper, a systematic literature review (SLR) is carried out in this paper. This method is proved to be effective in gathering, synthesizing, and appraising the findings of studies for one topic. Furthermore, this method covers a variety of 
disciplines and declines the bias in single research or nonsystematic reviews [30]. By the use of SLR, works were done including discussing the nature of project culture and influencing factors, the way to extract project culture, and investigating the project culture research focus in construction context. In this paper, we refined articles using the systematic literature review (SLR) proposed by Jesson et al. [31]. This systematic literature review mainly included three steps: comprehensive search, screen data by quality assessment, and group.

During this search, we made some criteria: (1) we searched the databases of ISI Web of Science, Elsevier, Scopus, Google Scholar, and the papers that appear in some conferences by the theme including both "project culture/ culture at project level/culture in project-based work" and "construction." And then we got a total number of 114 records belonging to ten fields, such as engineering, arts and humanities, agriculture, and biological. Next, (2) we restricted the papers to the construction industry, we excluded the construction material culture, and we got 48 papers. (3) After reading the titles, abstracts, and keywords of the papers, a total number of 37 papers were left, which must involve "project culture," "culture in project-based work," or "culture at project level." Considering the availability and relevance of the article, the type of paper was set as academic articles, conference papers, and review. Finally, we got 31 papers in fact.

Firstly, we searched on ISI Web of Science database and Scopus database with a theme of retrieval (the string search was set to TS = "project culture" and TS = "construction"), which included the titles, authors, and keywords. To refine the academic articles of this search, we browsed the titles, abstracts, and keywords. After this process, we got 37 papers left as the papers closely related to project culture in construction context. Then, we screened articles which involved a little bit of project culture. And the selected articles were carefully analyzed from beginning to end to ensure the relevance of the topic. After the examining process, a total number of 31 papers were selected and then we analyzed the full text of each paper (as shown in Figure 1).

Although there are some papers including project culture in their abstract, they have less to do with project culture. In this paper, we mainly try to analyze project culture in construction context so that some papers were excluded, in which project culture was just mentioned without contributions to project culture research. As a result, we chose a total number of 31 papers to analyze in the end (as shown in Table 1).

There are a total number of 31 papers for this aim in this study, which cover 11 conference papers. We pay more attention to the other 20 papers which make more contribution to research in project culture. The 31 papers can be mainly divided into 2 categories: the function, which treats project culture as a variable; and the nonfunction, which regards project culture as a root metaphor. The selected papers cover 2001 and 2019, written in English and published in scholarly journals. In the chosen papers, Samaraweera and Zuo make big contributions to project culture among those papers. Samaraweera stands the points of project culture as a root metaphor while Zuo agrees on the function paradigm and treats project culture as a variable.

\section{Findings}

After classifying the selected articles, two perspectives of project culture research are identified: the function and the nonfunction: "the function" where culture is something one organisation has, features with horizontal multidimensionality of project culture, and is prevailing in culture research; and "the nonfunction" where culture is something one organisation is, highlights the in-depth assumptions, and emphasizes the level from the outside to the inside of project culture. The selected papers covered project culture research in construction context including (1) the nature of project culture, (2) influence factors for project culture in construction context, (3) method to measure or extract project culture, and (4) research hotspot of project culture in construction context, such as the relationship between project culture and project performance and team efficacy.

4.1. The Nature of Project Culture. The essence of project culture is nebulous because there are multiple research perspectives which affect the methodology of analyzing project culture. There is a heated debate about the nature of the project culture about whether the project culture is the organisation itself or the attribute of the organisation. From the function paradigm, project culture considers culture to be an attribute of the organisation. It reflects the concept of real and objective, while from a nonfunctional paradigm, the project culture is the organisation itself. It reflects the thinking of the social reality in a given organisation.

From the nonfunction paradigm, project culture is divided into different layers on the basis of organisation culture models and it is interpretative. For example, three layers of culture included artifacts, espoused values, and beliefs $[54,55]$, and others proposed the fourth layers of culture, behaviour patterns [56]. A well-recognized culture model is Hofstede's, which contains symbols, heroes, rituals, and values and is used in project culture [57]. Similarly, Martin [58] divided project culture into three levels: espoused values, formal and informal practices, and the physical forms. Yan and Cao [40] provided four levels of project culture, including substance culture, conducts culture, system culture, and spirit culture. No matter how many layers project culture has, project culture can be divided into the visible section and the invisible section. The invisible section is the nature of project culture while the visible section is the externalization of project culture. It is easy to describe culture from the outer layer but the deep layer including assumptions and values is always hard to decipher. For example, the outer layer is the composite of rules and regulations, the office layout, and so on. While the deep layer is the way of thinking, there is a gap between the outer layers and inner layers of culture which may cause misunderstanding. Although the inner layer is difficult to detect, the manifestations of project culture provide scholars of cultural issues with new paths to decipher it. 


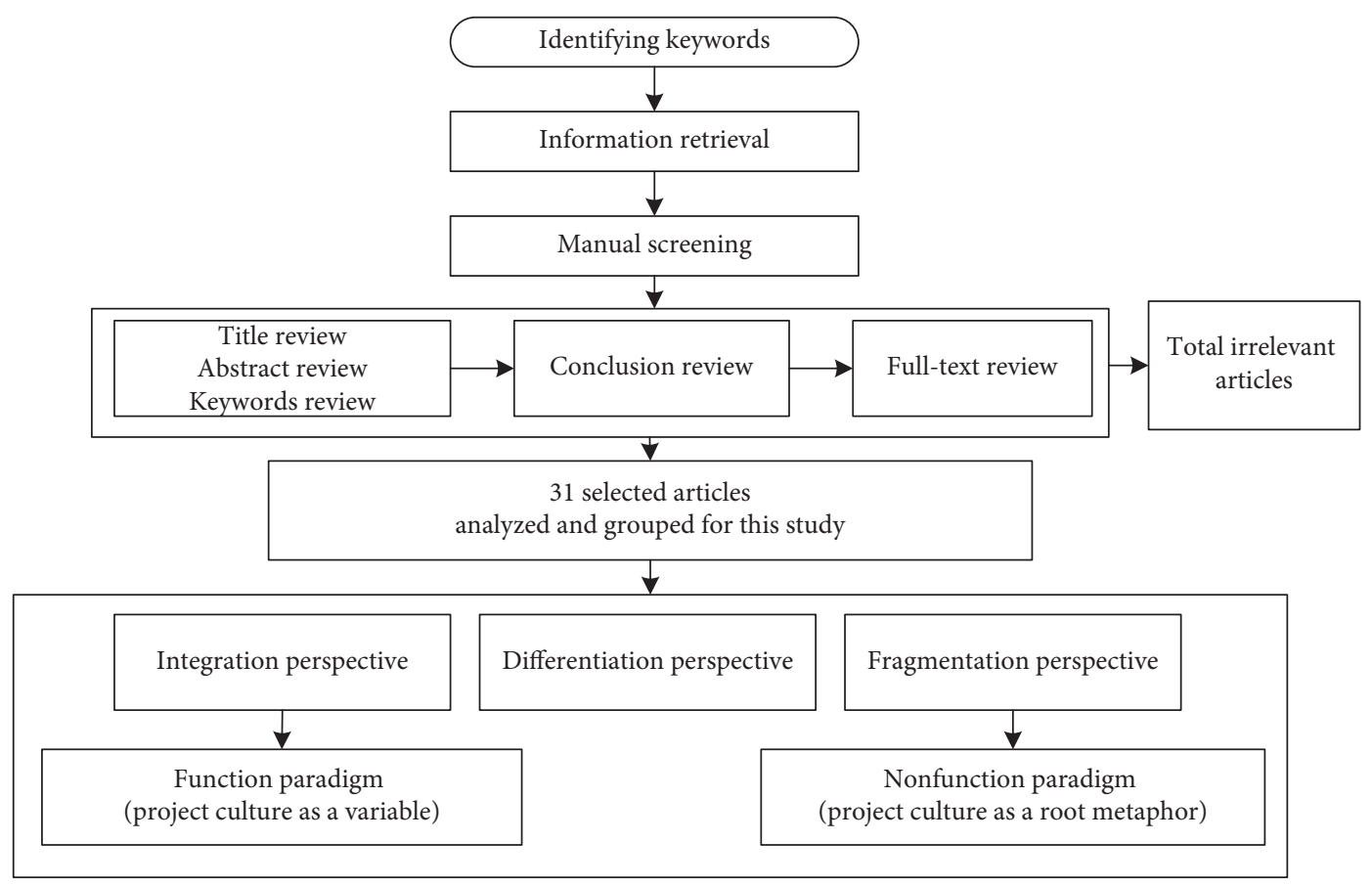

Figure 1: Overview of research methodology.

Scholars from the nonfunction paradigm try to extract the deep layer of project culture called values or underlying assumptions, no matter how many layers they divide. They focus on processes of meaning and sense making. However, most of scholars from the nonfunction paradigm pay attention to the deep layer of culture ignoring the research of shallow layers.

For the function paradigm, project culture is conceptualized as a variable and is accompanied by the horizontal multidimensionality. Ashkanasy et al. [59] proposed project culture with constructive and defensive characteristics which were shown in research of Aronson [44] and Walker et al. [60]. To figure out the origins and formation of project culture, Kumaraswamy et al. [61] described project culture by their impacts of subcultures including organisational subcultures, professional subcultures, operational subcultures, and individualistic subcultures. Zuo and Zillante [20] put forward a project culture model including integration, cooperation, goal orientation, flexibility, and people orientation, based on Cameron and Quinn's Competing Values Framework. This model was widely used in industry and academies. Ankrah et al. [62] classified project culture into five dimensions: workforce orientation, performance orientation, team orientation, client orientation, and project orientation. These models emphasize some characteristics of project culture and fail to fully express the project culture, and some dimensions of these models are coincident, such as goal orientation and performance orientation. In addition, the universality of the model is questioned. For example, the model of Zuo is only applicable to partner contracts. In spite of that, these models are used to elaborate the cultural differences between different participants as they came from various organisations such as consultants, clients, contracts, and other stakeholders [63]. Rameezdeen and Gunarathna
[17] compared project culture between contractors and consultants.

Among research from the function paradigm, they agreed on the positive and shared assumptions of project culture and project culture was generally identified as a variable from the completely shared perspective among all organisations. However, the project culture research from the function paradigm is descriptive and project culture is measured by some dimensions, which are made by expected outcomes of scholars. The dimensions are dependent on the expected outcomes and may be overlapped, which make it difficult for researchers to choose the appropriate model. The function paradigm simplifies culture into limited dimensions.

Both the function and nonfunction are trying to decipher project culture from different philosophy paradigms. From the integrated position, project culture contains unitive, harmonious, and shared values and assumptions within participants [64]. Characteristics of culture in integration, differentiation, and fragmentation are highlighted in their research. It depends on the degree of sharing to differentiate the three paradigms [65]. Changing from integration and differentiation to fragment orientations also depends on the controllability of culture [66]. Integration paradigm tries to develop sharing and positive project culture, which excludes ambiguity. Differentiation paradigm acknowledges the difference among organisations but still keeps culture as shared within organisations. From the perspective of fragment, there is a little culture of sharing and it aims at processes of meaning, sense making, and social construction of culture $[67,68]$. The adopted models of project culture in construction industry are shown in Table 2 from the three paradigms.

There are some scholars who applied the measurement of a well-recognized organisation culture instrument to 
TABLE 1: Overview of the 31 journal articles in this paper.

\begin{tabular}{|c|c|c|c|c|}
\hline Author(s) & Journals & Year & $\begin{array}{l}\text { The study country/ } \\
\text { areas }\end{array}$ & Titles \\
\hline $\begin{array}{l}\text { Riley and Clare- } \\
\text { Brown [9] }\end{array}$ & Journal of Management in Engineering & 2001 & UK & $\begin{array}{r}\text { Comparison of Cultures in } \mathrm{Cc} \\
\text { Manufacturing Ind }\end{array}$ \\
\hline Clegg et al. [32] & Organisation Studies & 2002 & Sydney, Australia & $\begin{array}{r}\text { Governmentality Matte } \\
\text { Alliance Culture of Inte } \\
\text { Collaboration for Mar }\end{array}$ \\
\hline Thomas et al. [23] & In Proceedings IGLC-10 & 2002 & Australia & $\begin{array}{l}\text { The Importance of Project Culture in } \\
\text { Achieving Quality Outcomes in Construction }\end{array}$ \\
\hline $\begin{array}{l}\text { Lindahl and } \\
\text { Josephson [33] }\end{array}$ & CIB TG 23 International Conference & 2003 & Sweden & $\begin{array}{c}\text { Managing Project Culture in Partnering } \\
\text { Projects-The Case of the Hotel Gothia } \\
\text { Towers Project }\end{array}$ \\
\hline $\begin{array}{l}\text { Rahman and } \\
\text { Kumaraswamy [34] }\end{array}$ & Journal of Management in Engineering & 2004 & $\begin{array}{l}\text { Hong Kong, } \\
\text { China }\end{array}$ & $\begin{array}{c}\text { Contracting Relationship Trends and } \\
\text { Transitions }\end{array}$ \\
\hline $\begin{array}{l}\text { Zuo and Zillante } \\
{[20]}\end{array}$ & $\begin{array}{l}\text { 13th International Group for Lean } \\
\text { Construction Conference: Proceedings }\end{array}$ & 2005 & - & $\begin{array}{r}\text { Project Culture within Cc } \\
\text { A Literature }\end{array}$ \\
\hline $\begin{array}{l}\text { Zuo and Zillante } \\
\text { [35] }\end{array}$ & $\begin{array}{r}\text { The International Journ } \\
\text { Managen }\end{array}$ & 2006 & South Australia & $\begin{array}{r}\text { Project Culture within } \mathrm{C} \\
\text { A Pilot Ca }\end{array}$ \\
\hline Zuo et al. [11] & $\begin{array}{r}\text { Cooperative Research } \\
\text { Construction Innoy }\end{array}$ & 2006 & South Australia & $\begin{array}{c}\text { The Client's Role in Driving an Appropriate } \\
\text { Project Culture Leading to Innovative } \\
\text { Performance Outcomes }\end{array}$ \\
\hline $\begin{array}{l}\text { Zuo and Zillante } \\
{[36]}\end{array}$ & Construction Information Quarterly & 2006 & South Australia & $\begin{array}{c}\text { Project Culture-The X Factor for Achieving } \\
\text { Optimum Performance in Construction } \\
\text { Projects? }\end{array}$ \\
\hline Van Marrewijk [24] & $\begin{array}{l}\text { International Journal of Project } \\
\text { Management }\end{array}$ & 2006 & The Netherlands & $\begin{array}{c}\text { Managing Project Culture: The Case of } \\
\text { Environ Megaproject }\end{array}$ \\
\hline $\begin{array}{l}\text { Zillante and Zuo } \\
\text { [37] }\end{array}$ & $\begin{array}{r}\text { International Con } \\
\text { National Constr }\end{array}$ & 2008 & - & $\begin{array}{c}\text { Construction Project Culture vs. National } \\
\text { Culture }\end{array}$ \\
\hline $\begin{array}{l}\text { Stehn and Höök } \\
\text { [37] }\end{array}$ & Lean Construction Journal & 2008 & Sweden & $\begin{array}{l}\text { Lean Principles in Industrialized Housing } \\
\text { Production: The Need for a Cultural Change }\end{array}$ \\
\hline $\begin{array}{l}\text { Höök and Stehn } \\
\text { [38] }\end{array}$ & $\begin{array}{r}\text { Construction } 1 \\
\text { Ecor }\end{array}$ & 2008 & Sweden & $\begin{array}{l}\text { Applicability of Lean Principles and Practices } \\
\text { in Industrialized Housing Production } \\
\text { Contributing beyond the Call of Duty: }\end{array}$ \\
\hline $\begin{array}{l}\text { Aronson and } \\
\text { Lechler [39] }\end{array}$ & R\&D Management & 2009 & The United States & $\begin{array}{c}\text { Examining the Role of Culture in Fostering } \\
\text { Citizenship Behaviour and Success in } \\
\text { Project-Based Work }\end{array}$ \\
\hline Yan and Cao [40] & $\begin{array}{l}\text { International Conference on Management } \\
\text { and Service Science, MASS } 2011\end{array}$ & 2011 & China & $\begin{array}{c}\text { Establishment and Realization of Project } \\
\text { Culture during the Construction Project } \\
\text { Management in China }\end{array}$ \\
\hline $\begin{array}{l}\text { Samaraweera and } \\
\text { Senaratne }[41]\end{array}$ & World Construction Conference 2012 & 2012 & - & $\begin{array}{l}\text { Understanding Project Culture in } \\
\text { Construction: A Literature Synthesis }\end{array}$ \\
\hline 1. [42] & Construction Economics and Building & 2012 & China & $\begin{array}{l}\text { Project Culture in the Chine } \\
\text { Industry: Perceptions of }\end{array}$ \\
\hline Zuo et al. [43] & Facilities & 2014 & South Australia & $\begin{array}{l}\text { Does Project Culture Matter? A Comparative } \\
\text { Study of Two Major Hospital Projects }\end{array}$ \\
\hline $\begin{array}{l}\text { Samaraweera et al. } \\
{[28]}\end{array}$ & $\begin{array}{l}\text { The 3rd World Construction Symposium } \\
\qquad 2014\end{array}$ & 2014 & - & $\begin{array}{c}\text { Conceptual Framework for Understanding } \\
\text { Construction Project Culture: A Literature } \\
\text { Review }\end{array}$ \\
\hline Aronson [44] & $\begin{array}{l}\text { International Journal of Innovation and } \\
\text { Technology Management }\end{array}$ & 2015 & $\begin{array}{l}\text { The Northeastern } \\
\text { US }\end{array}$ & $\begin{array}{c}\text { An Investigation of the Role of Project } \\
\text { Culture in Team Efficacy and Success in } \\
\text { Project-Based Work }\end{array}$ \\
\hline Butt et & $\begin{array}{c}\text { International Journal of Project } \\
\text { Management }\end{array}$ & 2016 & Asia and Finland & Project Change Stakeholder Communication \\
\hline Zheng et al. [46] & Sustainability (Switzerland) & 2017 & China & $\begin{array}{c}\text { Ambidextrous Leadership and Sustainability- } \\
\text { Based Project Performance: The Role of } \\
\text { Project Culture }\end{array}$ \\
\hline $\begin{array}{l}\text { Samaraweera et al. } \\
\text { [47] }\end{array}$ & $\begin{array}{c}13^{\text {th }} \text { International Postgraduate Research } \\
\text { Conference } 2017\end{array}$ & 2017 & Sri Lanka & $\begin{array}{l}\text { Three Perspectives of Public Sector } \\
\text { Construction Project Culture: An } \\
\text { Exploratory Case Study in Sri Lanka }\end{array}$ \\
\hline
\end{tabular}


TABLE 1: Continued.

\begin{tabular}{|c|c|c|c|c|}
\hline Author(s) & Journals & Year & $\begin{array}{l}\text { The study country/ } \\
\text { areas }\end{array}$ & Titles \\
\hline $\begin{array}{l}\text { Samaraweera et al. } \\
{[48]}\end{array}$ & $\begin{array}{l}\text { The 6th World Construction Symposium } \\
\qquad 2017\end{array}$ & 2017 & Sri Lanka & $\begin{array}{c}\text { Nature of Existence of Public Sector } \\
\text { Construction Project Culture: An } \\
\text { Exploratory Case Study }\end{array}$ \\
\hline $\begin{array}{l}\text { Samaraweera et al. } \\
{[12]}\end{array}$ & $\begin{array}{c}\text { International Journal of Construction } \\
\text { Project Management }\end{array}$ & 2017 & Sri Lanka & $\begin{array}{l}\text { Conceptualizing Construction Project } \\
\text { Culture: Culture as a Root Metaphor as } \\
\text { Opposed to the Culture as a Variable }\end{array}$ \\
\hline Aronson [49] & $\begin{array}{c}\text { International Journal of Innovation and } \\
\text { Technology Management }\end{array}$ & 2018 & - & $\begin{array}{l}\text { An Investigation of Culture and Contextual } \\
\text { Performance in Projects: What Is the Role of } \\
\text { Project Leader Personal Style Differences? }\end{array}$ \\
\hline Zuo et al. [43] & Facilities & 2018 & South Australia & $\begin{array}{c}\text { Does Project Culture Matter? A Comparative } \\
\text { Study of Two Major Hospital Projects }\end{array}$ \\
\hline $\begin{array}{l}\text { Samaraweera et al. } \\
\text { [50] }\end{array}$ & $\begin{array}{c}\text { Built Environment Project and Asset } \\
\text { Management }\end{array}$ & 2018 & Sri Lanka & $\begin{array}{l}\text { Nature of Construction Project Cultures in } \\
\text { the Public Sector: Case Studies in Sri Lanka }\end{array}$ \\
\hline $\begin{array}{l}\text { Samaraweera et al. } \\
\text { [51] }\end{array}$ & $\begin{array}{c}\text { International Journal of Construction } \\
\text { Management }\end{array}$ & 2018 & $\begin{array}{l}\text { Colombo urban } \\
\text { area in Sri Lanka }\end{array}$ & $\begin{array}{l}\text { Methodology to Extract Underlying Basic } \\
\text { Assumptions of a Public Sector Construction } \\
\text { Project Culture: An Exploratory Case Study }\end{array}$ \\
\hline $\begin{array}{l}\text { Samaraweera et al. } \\
\text { [52] }\end{array}$ & $\begin{array}{l}\text { The 7th World Construction Symposium } \\
2018\end{array}$ & 2018 & Sri Lanka & $\begin{array}{l}\text { Basic Assumptions of Contractor's Sub- } \\
\text { Culture in Public Sector Building } \\
\text { Construction Projects in Sri Lanka }\end{array}$ \\
\hline $\begin{array}{l}\text { Samaraweera et al. } \\
\text { [53] }\end{array}$ & $\begin{array}{c}\text { Proceedings of the 11th International Cost } \\
\text { Engineering Council (ICEC) World } \\
\text { Congress and the 22nd Annual Pacific } \\
\text { Association of Quantity Surveyors } \\
\text { Conference }\end{array}$ & 2018 & Sri Lanka & $\begin{array}{l}\text { Cultural Basic Assumptions of Consultant } \\
\text { Sub-Culture in Public Sector Construction } \\
\text { Projects: Case Studies in Sri Lanka }\end{array}$ \\
\hline
\end{tabular}

TABLE 2: Components of project culture in construction project.

\begin{tabular}{|c|c|}
\hline Author(s) & Components of project culture \\
\hline Thomas et al. [23] & Clan culture, market culture, adhocracy culture, and hierarchy culture \\
\hline Kumaraswamy et al. [61] & Organisational culture, operational culture, individual culture, and professional culture \\
\hline Zuo et al. [11] & Integration, cooperation, goal-oriented, flexible, and people oriented \\
\hline Iarrewijk [24] & Gideon's gang and the Diplomats \\
\hline $\begin{array}{l}\text { Aronson and Lechler } \\
\text { [39] }\end{array}$ & Constructive culture and defensive culture \\
\hline Ankrah et al. [62] & Workforce orientation, performance orien \\
\hline Yan and Cao [40] & Subs \\
\hline Samaraweera et al. [47] & $\begin{array}{l}\text { Systems of thoughts, a symbolic perspective, and structural and psychodynamic perspective (underlying basic } \\
\text { assumptions) }\end{array}$ \\
\hline
\end{tabular}

project culture. For example, Teräväinen et al. [69] used Cameron and Quinn's Competing Values Framework (CVF 2011) model to project culture. It is inappropriate because these models ignore the characteristics of construction project, such as the uniqueness and temporariness. In the future, it is urgent to deeply study project culture and develop culture models in construction projects.

4.2. Factors Influencing Project Culture. There are plenty of stakeholders in construction projects and the personnel turnover in construction project is high during project life cycle. Project culture plays a role in helping newcomers adapt to the construction environment. With the change of project phases, project culture develops with time. With the aim of deciphering project culture, it is necessary to find the critical factors influencing it. Due to the complexity of project culture, it is difficult to explore the nature by its manifestation. A big number of researchers analyze the factors influencing project culture, such as Kumaraswamy et al. [61], Ankrah and Langford [16], and Zuo et al. [11]. In this paper, three categories of project culture are mainly classified: national culture, project properties, and organisation properties. Here, individual characteristics are put into organisation property.

The national culture has impact on project culture [70]. Hofstede proposed national culture model from the crossculture perspective which included power distance, uncertainty avoidance, individualism and collectivism, femininity-verses masculinity, and long-verses short-term orientation [71]. This model is usually used to study project culture. For instance, Zuo and Zillante [25] studied how national culture influences construction project culture between Australia and China. In Australia, they were willing to accept risk, low power distance, individualism, and masculinity while culture in China tended to high 
uncertainty and risk avoidance, large power distance, and collectivism. Liang and Whiteley [72] used ground research and found that Australians paid more attention than Chinese. Van Marrewijk [24] revealed that project culture in European construction comprised innovation, creativity, nontraditionalism, and independence, while project culture in China was dominated by outcome-oriented, high power distance, collectivism, and high uncertainty avoidance. Also, interpersonal relationships with other participants were important as well [42]. Samaraweera et al. [47] analyzed project culture in Sri Lanka from perspectives of integration, differentiation, and fragmentation.

As for project properties, project culture is shaped by the feature of projects such as the duration of projects, the ways of procurement, the geographical environment, and the size of projects. Albert Eddy Husin uncovered culture in highrise building which constituted high complexity of work. In practice, the creation of project culture in mega projects was usually paid more attention. Kwan and Ofori [73] revealed that prior experience and relationship have a significant impact on project culture. Ankrah et al. [74] identified key project features which had an effect on culture, including project size, complexity, stakeholders, location, and the cost of health and safety. Ankrah deemed that there was no relationship between culture and the adopted procurement. Interestingly, Zuo deemed that project culture was influenced by the procurement approach and pointed out that partnering contracts as well as alliancing approach are benefited for integration. Both of them agreed on openness among all parties, the understanding of each other's business, and the unification of personal interests driving to cooperate successfully. Furthermore, project culture in megaproject was especially different from culture in general construction [36]. Furthermore, whether the project belonged to the public or not made a difference to project culture. Obviously, the private sector is different from the public sector in terms of the unique characteristics of the external environment and internal integration. For example, Samaraweeraa et al. [51] explored project culture in the public sector from the nonfunction paradigm and used the value orientation theory (VOT) to detected underlying assumptions of project culture. However, it was only the public sector. Nutt pointed out that the private sector was driven by self-interests while the public sector aimed at public interests like Lyons' research. Notable among these influences are goals, values and commitment, innovation, and outcome orientation [75-77].

The organisation properties describe that project culture is influenced by the structure, the leadership style, the prehistory of organisations, the choice of project manager, the selection of participants, and the personal ability of them. Zuo detected project culture from participants of the contractors, the clients, and the owners. Aronson [49] explored the influence of leader styles on project culture. Furthermore, Zheng et al. [46] pointed out that ambidextrous leadership positively influenced ambidextrous culture. Kumaraswamy et al. [70] shed light on professional and individualistic subcultures. They all have impacts on project culture. Additionally, project culture varied in different type of organisations, that is, matrix organisation and project centric organisation. Furthermore, it concluded that there were critical factors shaping project culture including project teams, client environment, project objectives, and parent organisation type. Van Marrewijk [24] explored the role of project managers in project culture change.

All in all, project is at odds with organisation culture or project team culture. It is not feasible to apply the theory of organisational culture directly to the research of project culture, which can be found in Gupta's research [78]. Therefore, the research of project culture sought to examine the three types of factors in project context.

4.3. Extraction of Project Culture. The philosophy used to define project culture determines the way in which project culture is explored. To decipher project culture, both qualitative and quantitative methods are used in this field.

Qualitative methods are from the perspective of nonfunction and interpret the cultural issues, such as interviews, on-site observations, and anthropological fieldwork methods, which explain culture in a given context. For example, Samaraweera et al. adopted case study to decipher project culture in a building construction project in Sri Lanka by Kluckhohn and Strodtbeck's value orientation theory (VOT) [51]. Also, Van Marrewijk used the mixed method for project culture in Environ Megaproject including biographical interviews, observation, and desk research [24]. By the use of qualitative methods, the deep assumptions could be disclosed. However, with the help of qualitative methods, the nature of project culture can be extracted which depends on the ability of the researcher. The theory of Shein in culture is popular in qualitative methods of project culture which is on the basis of interviews, ethnography, and observations. This approach provides lots of in-depth information about the organisation. For example, a triangulation method was used in project culture of the Environ Megaproject through external forces and carefully analyzed the cultural content, practice, and cultural forms of different periods. Similarly, Bonghez [79] used case study to analyze project culture via project values and logos, project rules, project habits, and project-related artifacts and also project plans used for communication purposes, project-related events, and project scorecard in practice.

However, qualitative methods make it impossible to compare studies and have difficulties in hypothesis testing and theoretical construction. Quantitative research methods make up for this deficiency.

The advantage of quantitative methods is that they have the potential to overcome the subjectivity of the qualitative methods. For example, questionnaires can cover a large number of samples. The comparison between studies is also possible and more objective. Scholars from the function paradigm prefer to adopt the quantitative methods which provide a general frame of cultural issues. Project culture can be evaluated and studied through certain characteristic and different dimensions and advocated quantitative evaluation by scales and questionnaires. For example, Aronson based on the Structural Equation Model is analyzing project 
culture and contextual performance. Nevertheless, the quantitative method provides simple explanations of project culture [49]. Notable scholars of empirical studies on project culture in quantitative methods are Aronson [44], Thomas [23], and Kumaraswamy et al. [80]. However, there are disadvantages of quantitative methods. For example, it is hard to choose the right model in questionnaire and researchers are dominated by their own cultural views rather than revealing the actual culture. Furthermore, quantitative methods just shed light on culture phenomena but not beyond the surface of project culture.

Given the shortcomings of using single quantitative or qualitative methods, the mixture of qualitative and quantitative methods has been used for a reliable measure of project culture. For example, Zuo conducted the mixed method to explore project culture in two major hospital projects by questionnaire survey and in-depth interviews from the function paradigm. His research absorbed the advantages of qualitative research and quantitative research. This mixed method is also evident in Zhentao Zhu's research [81]. And Zuo made a comparison between 2 hospital projects by questionnaire surveys, in-depth interviews, and review of project documents.

In construction industry, the quantitative method is more popular with researchers [19]. That is to say, there is an agreement on the function paradigm where project culture works as a variable. Through the above review of the research literature on quantitative method, we can see that many researches attempt to summarize the project culture with a limited dimension. Although these studies are somewhat one-sided and it is difficult to truly, comprehensively, and accurately clarify the dimensions of project culture, there are agreements on people and project goal. Due to the function paradigm, project culture can be controlled and be measured by dimensions. However, this method is at risk of ignoring the nature of project culture.

The nonfunction paradigm which mostly adopted the quantitative method disagreed with the function paradigm and proposed to extract the nature of project culture. In most research, the nature of project culture is recognized as the underlying assumptions or values of project culture which are hard to manage and manipulate. Samaraweera made a comparison between the two philosophy positions and preferred the nonfunction paradigm. As for the analysis of function paradigm, she analyzed project culture from corporate culture studies and comparative management studies in which culture was materialized. From the nonfunction paradigm, culture was abstract. In fact, there is a lack of research in construction project context that takes this nonfunction paradigm. Obviously, it depends on the purpose to diagnose project culture.

On the diagnosis of project culture, it is obvious that there are large differences in the measure project culture which reflects the various definition of project culture. The function paradigm emphasizes dimensions to describe project culture while the nonfunction paradigm highlights underlying assumptions or values. Despite the lack of consensus, both of them agree that project culture plays a role in project life cycle.
4.4. Research Focus. In recent years, research hotspots on project culture have focused on antecedent research and consequence studies. In antecedent research, research explained the creation of appropriate project culture and tried to distinguish project culture from other cultures. In consequence studies, a lot of studies focused on the positive relationship between project culture and project performance, which was more common in the research from the function paradigm. And the function paradigm on project culture is more popular than the nonfunction paradigm in prior research.

From the selected papers, Riley and Clare-Brown [9] made a comparison of cultures in construction and manufacturing industries and noted that the culture in construction was treated as project culture while the culture in manufacturing was treated as company culture. In Riley's research, the NEDO model of culture was used, which was proposed by the National Economic Development Office (NEDO) in 1990. Findings showed that project culture in construction was less clearly defined and less innovative than manufacturing industries. One point needs to be emphasized, there is just one company chosen by Riley to differ project culture from company culture, which needs more proofs.

Clegg et al. [32] considered project culture a management tool to glue kinds of stakeholders. For a better outcome, most scholars researched a positive project culture. Göran Lindahl conducted a case study of a partnering project called the Hotel Gothia Tower project in order to manage project culture [82]. Zuo et al. [42] investigated the procurement approach in construction project, which impacted project culture. Comparing the traditional hard money contract, the partnering and alliancing contracts were easier to develop a collaborative and cooperative project culture. Rahman and Kumaraswamy [34] applied relational contracting principles for the joint management of risks to develop appropriate project culture.

However, project culture may be a barrier sometimes. Turner et al. [83] found that project culture was a barrier for work-life balance in a construction project. In 2014, Anderson et al. [84] stated that project culture in construction context had advantages and disadvantages on absence rates and suggested that stable project structure helped the spread of negative culture or positive culture.

There are many scholars who pay attention to the relationships between project culture and project performance. Zheng et al. [46] researched Chinese construction projects and found the relationships among ambidextrous leadership, ambidextrous culture, and sustainability-based project performance. Teräväinen et al. [69] used the organisational culture assessment instrument to measure project culture in the Finish construction industry through 30 case projects and suggested that a strong comprehensive culture supported better efficiency outcomes. Ekström et al. [85] tried to integrated project team performance in early designed stages of Swedish bridge construction projects and addressed three essential cornerstones of value creation: culture, structure, and competence from three hierarchy levels including the organisation, project, and the individual level. Furthermore, Aronson [49] investigated how culture in project-based work boosted behaviour outcomes and success in project and proposed that project culture could be 


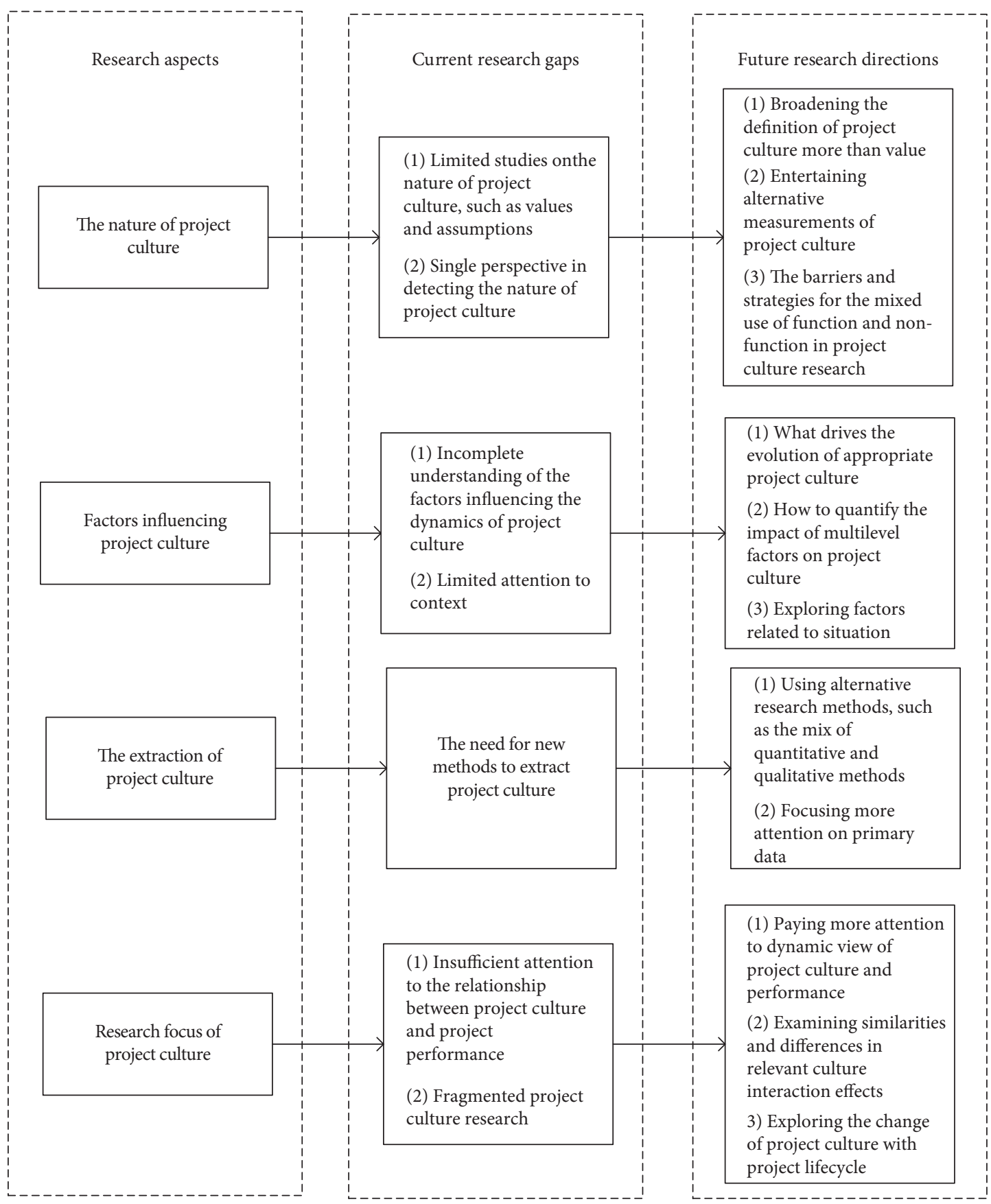

Figure 2: The framework of main research gaps and future directions of project culture.

used by leaders to initiate contextual performance. Although there is a relationship between culture and performance, the mechanism is still a black box.

Furthermore, in most general construction projects, the development of project culture is usually replaced by mandatory management, because the development of project culture takes a long time while the construction project is short-lived. Megaprojects in construction context provide a good opportunity to create project culture, which is different from corporate organisational structure and general temporary organisation structure. For example, Van Marrewijk [24] explored the case of Environ Megaproject to analyze its project culture especially in the transition of project phase. Project culture as the root metaphor was applied including three classification: espoused and inferred cultural values orientations, the formal and informal practices, and the cultural forms such as stories and heroes. Furthermore, a comparison between two megaprojects of The Netherlands and Australia was made which suggested that project culture evolved during the project life cycle. Similarly, Butt et al. [45] explored the evolution of project culture in project change management. Changes in project culture would lead to a dysfunction phase which was full of frustration, isolation, the shortage of innovation, and the loss 
of adaptability to environment [24]. Those studies provide a dynamic direction for future research of project culture.

This study proposes a framework of project culture research based on the above discussion. The research gaps and the corresponding research directions of project culture in construction are shown in Figure 2.

\section{Conclusions}

Project culture in construction context has been increasingly popular among scholars who believe that it helps improve project performance over the last decades. Construction industry is often known as being technology-driven and it is time to make an in-depth understanding of project culture. Prior work has documented the effectiveness of project culture in improving project performance and achieving specific project team performance. From the extant literature on project culture, it concludes that the research methodologies are from either the function paradigm known as integration positions in philosophy or the nonfunction paradigm known as fragmentation positions. With the function paradigm, project culture is treated as a variable and is delegated by limited dimensions. There is a continuous debate on project culture dimensions. Under the circumstance, project culture is highly shared in all project organisations which achieve unity. Under the nonfunction paradigm, project culture is regarded as a root metaphor, highlighting the underlying assumptions and the levels from the outside to the inside of project culture. Sometimes, the outside of project culture is inconsistent with the inside and project culture is unshared in the project organisations which includes ambiguity. Actually, project culture in project organisations is shared to some extent and is a hybrid paradigm of the above two paradigms, which is known as the differentiation position in philosophy. It provides the researchers with a new idea of hybrid paradigms. Under the hybrid paradigm, it is necessary to study project culture, both the outer manifestation and the inner assumptions of project culture, because of its inconsistency. For example, Yan and Cao studied project culture from substance culture, conducts culture, regulations culture, and spirits culture [40]. The hybrid paradigm provides a new way to extract the authentic project culture which needs further research in the future.

\section{Data Availability}

The data are available upon request from the corresponding author.

\section{Conflicts of Interest}

The authors declare no conflicts of interest.

\section{Acknowledgments}

This work was supported by the National Natural Science Foundation (Grant no. 71971161) and the special funds for the basic scientific research operating expenses of Beijing Municipal Colleges and Universities (Grant nos. X18174 and $\mathrm{X} 18053)$.

\section{References}

[1] M. Hobday, "The project-based organisation: an ideal form for managing complex products and systems?" Research Policy, vol. 29, no. 7-8, pp. 871-893, 2000.

[2] C. Jones and B. B. Lichtenstein, "Temporary inter-organisational projects," in The Oxford Handbook of Inter-Organisational Relations, Oxford Handbook of Publishing, Oxford, UK, 2008.

[3] A. Guide, "Project management body of knowledge (pmbok ${ }^{\circledR}$ guide)," Project Management Institute, Newtown Square, PA, USA, 2001.

[4] B. Ozorhon, D. Arditi, I. Dikmen, and M. T. Birgonul, "Implications of culture in the performance of international construction joint ventures," Journal of Construction Engineering and Management, vol. 134, no. 5, pp. 361-370, 2008.

[5] K. Tone, M. Skitmore, and J. K. W. Wong, "An investigation of the impact of cross-cultural communication on the management of construction projects in Samoa," Construction Management and Economics, vol. 27, no. 4, pp. 343-361, 2009.

[6] M. M. Kumaraswamy, A. M. Anvuur, and H. J. Smyth, "Pursuing "relational integration" and "overall value" through "RIVANS"," Facilities, vol. 28, no. 13-14, pp. 673-686, 2010.

[7] J. Mueller, "A specific knowledge culture: cultural antecedents for knowledge sharing between project teams," European Management Journal, vol. 32, no. 2, pp. 190-202, 2014.

[8] W. F. Maloney and M. O. Federle, Organisational Culture in Engineering and Construction Organisations, Bureau of Engineering Research, University of Texas at Austin, Austin, TX, USA, 1990.

[9] M. J. Riley and D. Clare-Brown, "Comparison of cultures in construction and manufacturing industries," Journal of Management in Engineering, vol. 17, no. 3, pp. 149-158, 2001.

[10] M. Henrie and A. Sousa-Poza, "Project management: a cultural literary review," Project Management Journal, vol. 36, no. 2, pp. 5-14, 2005.

[11] Zuo J., Ness D., Zillante G., 2006, The Client's Role in Driving an Appropriate Project Culture Leading to Innovative Performance Outcomes: In Contexts of Australia and China. The Rights of the Authors to be Identified as the Authors of this Work has been Asserted in Accordance with the Copyright Act 1968. All Rights Reserved, This Book is Copyright. Other than for the Purposes of and Subject to the Conditions Prescribed under the Copyright Act, No Part of it may be in Any Form or by Any Means (Electronic, Mechanical, Microcopying, Photocopying, Recording or Otherwise).

[12] A. Samaraweera, S. Senaratne, and Y. G. Sandanayake, "Conceptualising construction project culture: culture as a root metaphor as opposed to the culture as a variable," International Journal of Construction Project Management, vol. 9, no. 1, pp. 19-35, 2017.

[13] T. Gajendran, G. Brewer, A. R. J. Dainty, and G. Runeson, “A conceptual approach to studying the organisational culture of construction projects," Australasian Journal of Construction Economics \& Building, vol. 12, no. 2, pp. 1-26, 2012.

[14] C. C. Tsai and M. Lydia Wen, "Research and trends in science education from 1998 to 2002: a content analysis of publication in selected journals," International Journal of Science Education, vol. 27, no. 1, pp. 3-14, 2005.

[15] R. Müller, K. Spang, and S. Ozcan, "Cultural differences in decision making in project teams," International Journal of Managing Projects in Business, vol. 2, no. 1, pp. 70-93, 2009. 
[16] N. A. Ankrah and D. A. Langford, "Architects and contractors: a comparative study of organizational cultures," Construction Management and Economics, vol. 23, no. 6, pp. 595-607, 2005.

[17] R. Rameezdeen and N. Gunarathna, "Organisational culture in construction: an employee perspective," Construction Economics and Building, vol. 3, no. 1, pp. 19-30, 2012.

[18] L. Von Bertalanffy, General System Theory: Foundations, Development, Applications, George Braziller, Manhattan, NY, USA, 1969.

[19] R. Fellows and A. M. M. Liu, "Use and misuse of the concept of culture," Construction Management and Economics, vol. 31, no. 5, pp. 401-422, 2013.

[20] J. Zuo and G. Zillante, "Project culture within construction projects: a literature review," in Proceedings of the 13th International Group for Lean Construction Conference, p. 353, Sydney, Australia, July 2005.

[21] G. Hofstede and G. J. Hofstede, Cultures and Organisations: Software of the Mind, McGraw-Hill Education, New York, NY, USA, 2nd edition, 2005.

[22] D. L. Duarte and N. T. Snyder, Mastering Virtual Teams: Strategies, Tools, and Techniques that Succeed, John Wiley \& Sons, Hoboken, NJ, USA, 2006.

[23] R. Thomas, M. Marosszeky, K. Karim, S. Davis, and D. McGeorge, "The importance of project culture in achieving quality outcomes in construction," Proceedings IGLC, vol. 10, pp. 1-13, 2002.

[24] A. Van Marrewijk, "Managing project culture: the case of environ megaproject," International Journal of Project Management, vol. 25, no. 3, pp. 290-299, 2007.

[25] J. Zuo and G. Zillante, Construction Project Culture vs $\mathrm{Na}$ tional Culture, CIB, Bracknell, UK, 2008.

[26] N. Udawatta, J. Zuo, K. Chiveralls, and G. Zillante, Integrating the Dancers with the Dance: Acknowledging the Notion of Construction Project Culture-A Literature Review, AUBEA \& Unitec, Auckland, New Zealand, 2013.

[27] A. U. A. A. Samaraweera and S. Senaratne, "Understanding project culture in construction: a literature synthesis," in Proceedings of the World Construction Symposium 2012: Global Challenges in Construction Industry, pp. 314-322, Colombo, Sri Lanka, June 2012.

[28] A. Samaraweera, Y. Sandanayake, and S. Senaratne, "Conceptual framework for understanding construction project culture: a literature review," in Proceedings of the 3rd World Construction Symposium 2014: Sustainability and Development in Built Environment, pp. 116-126, Colombo, Sri Lanka, June 2014

[29] N. A. Ankrah and D. Proverbs, "Treading the softer areas of construction management: a critical review of culture," in Proceedings of the 20th Annual ARCOM Conference, pp. 1-3, Reading, UK, September 2004.

[30] M. Sweet and R. Moynihan, Improving Population Health; the Uses of Systematic Reviews, Milbank LLP, New York, NY, USA, 2007.

[31] J. Jesson, L. Matheson, and F. M. Lacey, Doing Your Literature Review: Traditional and Systematic Techniques, Sage, Thousand Oaks, CA, USA, 2011.

[32] S. R. Clegg, T. S. Pitsis, T. Rura-Polley, and M. Marosszeky, "Governmentality matters: designing an alliance culture of inter-organizational collaboration for managing projects," Organization Studies, vol. 23, no. 3, pp. 317-337, 2002.

[33] G. Lindahl and P. E. Josephson, "Managing project culture-the case of the hotel gothia towers project," in Proceedings of the CIB
TG 23 International Conference Professionalism in Construction: Culture of High Performance, Hong Kong, China, October 2003.

[34] M. M. Rahman and M. M. Kumaraswamy, "Contracting relationship trends and transitions," Journal of Management in Engineering, vol. 20, no. 4, pp. 147-161, 2004.

[35] J. Zuo and G. Zillante, "Project culture within construction projects-a pilot case study," International Journal of Construction Management, vol. 6, no. 2, pp. 15-29, 2006.

[36] J. Zuo and G. Zillante, "Project culture-the $\mathrm{X}$ factor for achieving optimum performance in construction projects?" Doctoral dissertation, Chartered Institute of Building, Bracknell, UK, 2006.

[37] L. Stehn and M. Höök, "Lean principles in industrialized housing production: the need for a cultural change," Lean Construction Journal, pp. 20-33, 2008.

[38] M. Höök and L. Stehn, "Applicability of lean principles and practices in industrialized housing production," Construction Management and Economics, vol. 26, no. 10, pp. 1091-1100, 2008.

[39] Z. H. Aronson and T. G. Lechler, "Contributing beyond the call of duty: examining the role of culture in fostering citizenship behavior and success in project-based work," R\&D Management, vol. 39, no. 5, pp. 444-460, 2009.

[40] X. Yan and H. Cao, "Establishment and realization of project culture during the construction project management in China," in Proceedings of the 2011 International Conference on Management and Service Science, pp. 1-4, IEEE, Wuhan, China, August 2011.

[41] A. U. A. A. Samaraweera and S. Senaratne, "Understanding project culture in construction: a literature synthesis," in Proceedings of the World Construction Conference 2012-Global Challenges in Construction Industry, Colombo, Sri Lanka, June 2012.

[42] J. Zuo, G. Zillante, and V. Coffey, "Project culture in the Chinese construction industry: perceptions of contractors," Australasian Journal of Construction Economics \& Building, vol. 9, no. 2, pp. 17-28, 2012.

[43] J. Zuo, G. Zillante, Z.-Y. Zhao, and B. Xia, "Does project culture matter? A comparative study of two major hospital projects," Facilities, vol. 32, no. 13-14, pp. 801-824, 2014.

[44] Z. H. Aronson, "An investigation of the role of project culture in team efficacy and success in project-based work," International Journal of Innovation and Technology Management, vol. 12, no. 6, Article ID 1550027, 2015.

[45] A. Butt, M. Naaranoja, and J. Savolainen, "Project change stakeholder communication," International Journal of Project Management, vol. 34, no. 8, pp. 1579-1595, 2016.

[46] J. Zheng, G. Wu, H. Xie, and H. Xu, "Ambidextrous leadership and sustainability-based project performance: the role of project culture," Sustainability, vol. 9, no. 12, p. 2336, 2017.

[47] A. Samaraweera, S. Senaratne, and Y. G. Sandanayake, "Three perspectives of public sector construction project culture: an exploratory case study in Sri Lanka," in Proceedings of the 13th International Postgraduate Research Conference, Manchester, UK, September 2017.

[48] A. Samaraweera, S. Senaratne, and Y. Sandanayake, "Nature of existence of public sector construction project culture: an exploratory case study," in Proceedings of the 6th World Construction Symposium 2017: What's New and What's Next in the Built Environment Sustainability Agenda?, pp. 308-315, Colombo, Sri Lanka, July 2017.

[49] Z. H. Aronson, "An investigation of culture and contextual performance in projects: what is the role of project leader personal style differences?" International Journal of 
Innovation and Technology Management, vol. 15, no. 4, Article ID 1850034, 2018.

[50] A. Samaraweera, S. Senaratne, and Y. G. Sandanayake, "Nature of construction project cultures in the public sector: case studies in Sri Lanka," Built Environment Project and Asset Management, vol. 8, no. 5, pp. 557-568, 2018.

[51] A. Samaraweera, S. Senaratne, and Y. G. Sandanayake, "Methodology to extract underlying basic assumptions of a public sector construction project culture: an exploratory case study," International Journal of Construction Management, vol. 18, no. 6, pp. 467-481, 2017.

[52] A. Samaraweera, S. Senaratne, and Y. G. Sandanayake, "Basic assumptions of contractor's sub culture in public sector building construction projects in Sri Lanka," in Proceedings of the 7th World Construction Symposium 2018, Built Asset Sustainability: Rethinking Design, Construction and Operations, Colombo, Sri Lanka, June 2018.

[53] A. Samaraweera, S. Senaratne, and Y. G. Sandanayake, "Cultural basic assumptions of consultant sub-culture in public sector construction projects: case studies in Sri Lanka," in Proceedings of the International Cost Engineering Council World Congress \& Pacific Association of Quantity Surveyors Conference, Sydney, Australia, November 2018.

[54] E. H. Schein, Organizational Culture and Leadership, JosseyBass, San Francisco, CA, USA, 2nd edition, 1992.

[55] M. J. Hatch, "The dynamics of organizational culture," The Academy of Management Review, vol. 18, no. 4, pp. 657-693, 1993.

[56] D. M. Rousseau, "Assessing organisational culture: the case for multiple methods," Organisational Climate and Culture, vol. 153, p. 192, 1990.

[57] G. Hofstede, B. Neuijen, D. D. Ohayv, and G. Sanders, "Measuring organizational cultures: a qualitative and quantitative study across twenty cases," Administrative Science Quarterly, vol. 35, no. 2, pp. 286-316, 1990.

[58] J. Martin, "Organisational culture, research paper series, research paper, (1847)," 2004.

[59] N. M. Ashkanasy, C. P. Wilderom, and M. F. Peterson, Handbook of Organisational Culture and Climate, Sage, Thousand Oaks, CA, USA, 2000.

[60] D. H. T. Walker, K. Hampson, and R. Peters, "Project alliancing vs project partnering: a case study of the Australian national museum project," Supply Chain Management: An International Journal, vol. 7, no. 2, pp. 83-91, 2002.

[61] M. Kumaraswamy, S. Rowlinson, M. Rahman, and F. Phua, Strategies for Triggering the Required "Cultural Revolution" in the Construction Industry, CIB, Bracknell, UK, 2002.

[62] N. A. Ankrah, D. Proverbs, and Y. Debrah, "Factors influencing the culture of a construction project organisation," Engineering, Construction and Architectural Management, vol. 16, no. 1, pp. 26-47, 2009.

[63] R. Fellows, T. Grisham, and W. Tijhuis, "Enabling project team culture," CIB Priority Theme-Revaluing Construction: A W065 "Organisation and Management of Construction" Perspective, vol. 27, 2007.

[64] D. Meyerson and J. Martin, "Cultural change: an integration of three different views," Journal of Management Studies, vol. 24, no. 6, pp. 623-647, 1987.

[65] M. Alvesson, Understanding Organisational Culture, Sage Publications, London, UK, 2002.

[66] M. Alvesson and H. Willmott, "On the idea of emancipation in management and organization studies," The Academy of Management Review, vol. 17, no. 3, pp. 432-464, 1992.

[67] T. S. Pitsis, S. R. Clegg, M. Marosszeky, and T. Rura-Polley, "Constructing the olympic dream: a future perfect strategy of project management," Organization Science, vol. 14, no. 5, pp. 574-590, 2003.

[68] K. E. Weick, "The social psychology of organizing," AddisonWestley, Reading, MA, USA, 1979.

[69] V. Teräväinen, J.-M. Junnonen, T. Salopää, and A. Sobolev, "Relationships between organisational culture and efficiency in Finnish construction projects," International Journal of Construction Management, pp. 1-15, 2018.

[70] M. Kumaraswamy, S. Rowlinson, and F. T. T. Phua, "Origins and desired destinations of construction project cultures," 2002.

[71] G. Hofstede, Culture's Consequences: Comparing Values, Behaviours, Institutions and Organisations Across Nations, Sage Publications, Thousand Oaks, CA, USA, 2001.

[72] S. Liang and A. Whiteley, "Australian businesses in China: searching for synergy," Asia Pacific Business Review, vol. 9, no. 3, pp. 41-60, 2003.

[73] A. Y. Kwan and G. Ofori, "Chinese culture and successful implementation of partnering in Singapore's construction industry," Construction Management and Economics, vol. 19, no. 6, pp. 619-632, 2001.

[74] N. Ankrah, D. Proverbs, A. Antwi, and Y. Debrah, "Factors influencing organisational culture: a construction project perspective," Building Research Summaries, vol. 16, no. 1, pp. 729-742, 2005.

[75] P. C. Nutt, "Comparing public and private sector decisionmaking practices," Journal of Public Administration Research and Theory, vol. 16, no. 2, pp. 289-318, 2005.

[76] S. T. Lyons, L. E. Duxbury, and C. A. Higgins, "A comparison of the values and commitment of private sector, public sector, and parapublic sector employees," Public Administration Review, vol. 66, no. 4, pp. 605-618, 2006.

[77] G. L. Harrison and K. M. Baird, "The organizational culture of public sector organizations in Australia," Australian Journal of Management, vol. 40, no. 4, pp. 613-629, 2015.

[78] A. Gupta, "Assessment of multi-project management: a survey report on multi-project management," 2003.

[79] S. Bonghez, "Building positive project culture for navigating complexity: A case study," PMI White Papers, Project Management Institute, Newtown Square, PA, USA, 2015.

[80] M. M. Kumaraswamy, M. M. Rahman, F. Y. Y. Ling, and S. T. Phng, "Reconstructing cultures for relational contracting," Journal of Construction Engineering \& Management, vol. 131, no. 10, pp. 1065-1075, 2005.

[81] Z. Zhu, "System complexity of project culture and its evolutionary mechanisms," Ph.D. thesis, University of Nanjing, China, 2012.

[82] G. Lindahl and P. Josephson, "Managing project culture in partnering projects-the case of the hotel gothia towers project," in Proceedings of the CIB TG 23 International Conference: Professionalism in Construction, Hong Kong, China, October 2003.

[83] M. Turner, H. Lingard, and V. Francis, "Work-life balance: an exploratory study of supports and barriers in a construction project," International Journal of Managing Projects in Business, vol. 2, no. 1, pp. 94-111, 2009.

[84] K. Anderson, S. Ahn, and S. H. Lee, "Social learning's effect on absenteeism: the effect of project turnover," in Proceedings of the Construction Research Congress, Atlanta, GA, USA, May 2014.

[85] D. Ekström, R. Rempling, and M. Plos, "Integrated project team performance in early design stages-performance indicators influencing effectiveness in bridge design," Architectural Engineering and Design Management, vol. 15, no. 4, pp. 249-266, 2019. 